\title{
ステロイド性アロマターゼ阻害剤：エストロゲン 生合成の特異的阻害剤
}

\section{Steroidal aromatase inhibitors : Specific inhibitors of estrogen biosynthesis}

\author{
沼 沢 光 輝 \\ 東北薬科大学
}

\begin{abstract}
Summary
Aromatase is the cyt. P-450 enzyme that mediates the biosynthesis of estrogens from androgen precursors. A large number of steroids have been evaluated as potential aromatase inhibitors, and they are classified into three groups, competitive inhibitor, affinity label and suicide substrate, according to their inhibition manner. Specific inhibitors of this enzyme have application as research tools for investigating aromatization mechanism, and are of pharmacological interest because of their possible use for treatment of estrogen-dependent deseases such as breast cancer and benign prostatic hyperplasia. Biochemical aspects of the activity of known steroidal aromatase inhibitors, their structure-activity relationships and their use for clinical treatment are discussed.
\end{abstract}

\section{ぬまざわみつてる}

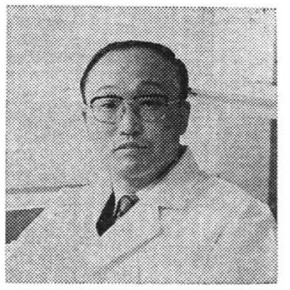

1967年東北大学医学部薬学科卒. 大学院博士課程修了後助手となり，1979年までの約14年 間南原利夫教授の基でステロイドホルモンの代謝・分析に関する研究の指導を受けた. 1980 年に東北薬科大学に移り現在に至っている. 1977年より 2 年間, 米国バッファロー市のバッ ファロー医学財団研究所内分泌生化学部門に留学し，アロマターゼの研究に接してきた．現 在，エストロゲンの生合成・代謝が主な研究テーマとなっているが，留学時代に学んだ有機 化学的手法を取り入れて, これら研究を進展させたいと考光ている. 妻と子供 2 人（912 歳, 07 歳) の家族であるが, 最近素性不明の猫 ( 9 約 0.3 歳) が新たに加わった. 


\section{1. はじめに}

アロマターゼ(以下 ARM と略) は, アンド ロゲン前駆体の 4-androstenedione (A) からエ ストロゲンの estrone $\left(\mathrm{E}_{1}\right)$ への変換を触媒する cyt. P-450 酵素である ${ }^{1)}$. 本酵素は, 性腺の他に 脂肪組織・筋肉 ${ }^{2)}$ や皮膚 ${ }^{3)}$ などにも分布する。ま た，胎盤ミクロゾームは ARM 酵素を約 $0.38 \%$ 含み ${ }^{4)}$ ，高い比活性を持つことから in vitro で の ARM 研究に酵素源としてよく用いられる.

ARM 阻害剂は, この酵素反応機構と活性部位 の特性を解明するのに大きな役割を果たすにとど まらず，エストロゲン依存性疾病（乳ガン，子宮 内膜症, 前立肥大症など）に有効な薬となりらる ものと期待されている，ここでは，われわれの研 究成果をまじえながらステロイド系阻害剤を取り 上げ，構造活性相関と活性発現機作の観点から述 ベるとともに，それらの臨床応用についても若干 触れてみたい。

\section{A環芳香核化 (ARM 反応機構)}

Fig. 1 に示すように, A の $\mathrm{E}_{1}$ への変換では 1 原子酸素添加反応が 3 回連続して起こる.まず, 19-hydroxy 体 (19-OHA) が生成し, 第 2 の水 酸化反応で 19-pro-R の水素が立体選択的に引き 抜かれ，19-gem-diol 1 となる. 1 は脱水し， 19-oxo 体 2 となった後, 3 回目の酸素化反応 で $\mathrm{C}_{10}-\mathrm{C}_{19}$ 結合が切断され，19-メチル基はギ酸とし て脱離するとともに，1 $\beta, 2 \beta$-水素が立体選択的に $\mathrm{H}_{2} \mathrm{O}$ として放出され， $\mathrm{E}_{1}$ が生成する ${ }^{6)}$. この最 後の酸素化反応については明確ではないが，19位
を攻撃し 19-peroxide を生成する機構》が，今ま での実験結果を最も矛盾なく説明するものとされ ている.この一連の反応は，一つの活性部位で連 続して進行する.

また, $16 \alpha$-水酸化ステロイドの化学合成も容易 になったこともあり ${ }^{8)}$, 最近, 妊婦で重要なエス トロゲンの estriol も, 前述と同じ経路で生合成 されることが確認されだ.

$\mathrm{ARM}$ 活性は，芳香核化機構に基づき， $\mathrm{A}^{5)}$ その $16 \alpha$-水酸体 ${ }^{10)}$ の $\left[1 \beta, 2 \beta-{ }^{3} \mathrm{H}\right]$ や $\left[1 \beta-{ }^{3} \mathrm{H}\right]$ 標識体を基質とし，遊離する ${ }^{3} \mathrm{H}_{2} \mathrm{O}$ を測定するラ ジオメトリック法が専ら用いられる。すた, 電気 化学的検出器を用いる HPLC による活性測定法 も試みられている ${ }^{11)}$. 本法は, ${ }^{3} \mathrm{H}$ 標識基質が利 用できない場合に用いられ，エストロゲン生成量 を直接定量するため信頼性が高い。

\section{3. ステロイド系 ARM 阻害剤とその阻害機 構}

阻害様式より，拮抗阻害剂，アフィニティラベ ル化剂, 自殺基質の 3 つに分けられるが，ここで は代表的なるのをそれぞれ取り上げる。

\section{3-1. 拮抗阻害剤}

$7 \alpha$-置換体 $3^{12)}$ と $4^{13)}$ と 3 -methylene 体 $7^{14)}$ が強力な阻害活性を持つ. $7 \alpha$-置換体では, この 活性発現に置換基のかさ高さや脂溶性が重要な因 子となる ${ }^{12,13,15)}$. 7 は，ステロイド系阻害剤と ARM との結合に 3 位カルボニル基が必須でない ことを明らかにした初めての化合物である.4 は，MCF-7 ヒト乳ガン細胞の ARM を阻害し， さらに, in vivo 実験で 7,12-dimethylbenz (a)

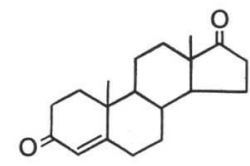

A<smiles>O=CC12CCC3C4CCC(=O)C=C4CCC3C1CCC2=O</smiles>

2

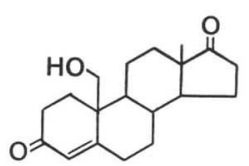

19-OHA

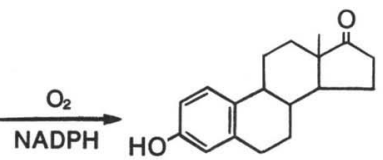

$\mathrm{E}_{1}$

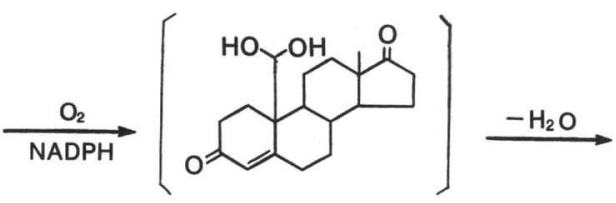

$\stackrel{1}{2}$

Fig. 1. Estrogen biosynthesis sequence. 


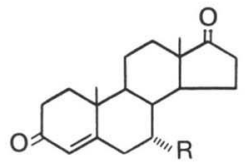

$\stackrel{3}{\sim}=\mathrm{C}_{2} \mathrm{H}_{5}$

$\stackrel{4}{\sim} \mathrm{R}=\mathrm{S}-\mathrm{ph}-\mathrm{NH}_{2}$

$5 \mathrm{R}=\mathrm{S}$-ph-NHCOCH $\mathrm{N}_{2} \mathrm{Br}$

6 R=S-ph- $\mathrm{N}_{3}$

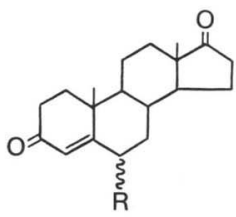

8 $\mathrm{R}=111 \mathrm{Br}$

$\stackrel{2}{2}=\triangleleft \mathrm{Br}$

$10 \mathrm{R}=1 \cdots \mathrm{OCOCH}_{2} \mathrm{Br}$

$11 \mathrm{R}=\boldsymbol{4} \mathrm{OCOCH}_{2} \mathrm{Br}$

Fig. 2. Competitive inhibitors and affinity labels of aromatase.

anthracene (DMBA) で誘発されたラットのエス トロゲン依存性乳ガンの腫瘍体積と血中エストロ ゲン濃度を顕著に縮小または低下させた ${ }^{16)}$.

\section{3-2. アフィニティラベル化剈}

ARM 活性部位に活性発現に必須な求核性官能 基の $\mathrm{SH}$ が存在する ${ }^{17)}$. そのため, 親電子的性 質を持ち化学的に活性な化合物が ARM のアフ ィニティ阻害剤として報告されている， $6 \alpha$-と $6 \beta$-bromo 体 8 と9では, $6 \alpha$-体のみが $\mathrm{O}_{2}$ なし で不可逆的に ARM を失活させた ${ }^{18)}$. 一方, $6 \beta$ bromo-17-bromoacetoxy 体 13 も NAPH なしで 擬一次反応的に酵素を失活させた。この場合， 17 $\beta$-置換基が関与するのであろ $5^{19)}$. 同様な立体選 択性が $6 \alpha$-と $6 \beta$-bromoacetoxy 体 10 と 11 でも 観察された ${ }^{19)}$. これら 6 位の立体化学は, 酵素之 阻害剂との結合の様相を考学るとき興味深い。 た， $7 \alpha$-thio 体については， $\left[{ }^{14} \mathrm{C}\right]-5$ が不可逆的 に酵素と結合し ${ }^{20)}$, azide 体 $\mathbf{6}$ は photoaffinity label として開発された ${ }^{21)}$.

一方, $\mathrm{E}_{1}$ 生合成中間体 19-OHA に似せて合 成された 10ß-hydroperoxide 12 は，NADPHな しで時間依存的に ARM を失活させた ${ }^{22)}$.これ
は，有機過酸による cyt. P-450 不活性化 ${ }^{23)}$ と同 様に, ARM 活性中心部位の $\mathrm{SH}$ 基が, スルフ ェニルに酸化されたためと考光られ，12 は一種の active-site-directed irreversible inhibitor と言光 る.

\section{3-3. 自殺基質}

Mechanism-based inhibitor とも呼ばれ，2， 3 の例外を除いてすべてが 4-en-3-one 構造を持 つ基質誘導体である。これはまず，ARM の活性 部位で酸素化を受け，化学的に活性な親電子的化 合物に変換される。ついで, この活性体は活性部 位より離れることなく，ただちに活性部位の $\mathrm{SH}$ 基と不可逆的に結合し，酵素を失活させる。この とき, $\mathrm{NADPH}$ と $\mathrm{O}_{2}$ 存在下 $\mathrm{ARM}$ 活性は時間 依存的に減少する.ARM 自殺基質ではラジオア イソトープ標識体の調製が困難なことから，不可 逆的結合の状態についてはほとんど検討されてい ない。このような阻害活性発現の機作から, 自殺 基質は ARM 反応機構解明に重要な情報を与兄 るばかりではなく, 特異性, 副作用, 持続性など に優れたエストロゲン依存性疾病の薬となりらる ことが期待されている.

3-3-1. $10 \beta$ ならびに 19 位誘導体 (Table I)

$\mathrm{ARM}$ 反応が 19-水酸化を伴うことから, 基質 A の19位誘導体や $10 \beta$-置換体がすず自殺基質と してあげられる。

1981年に Covey ら ${ }^{24)}$ とより, 基質 A と19OHA の 19-エチニル誘導体 14 と 15 が, 初めて の19-置換 ARM 自殺基質として報告された. 14 は特に強い阻害活性を示した。また，15について は，(S)-ジアステレオマーのみが自殺基質とな る. この立体選択性は, $\mathrm{E}_{1}$ 生合成過程で 2 番目の 水酸化反応が立体選択的であることと関連してい るのかもしれない。

これら化合物の不活性化機構として, Fig. 3 飞

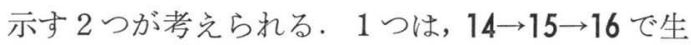
成する 19-oxo 体 16 のエチニル基に ARM の SH が Michael 付加する経路 (A) ${ }^{24)}$ で, 他は, 末端 アセチレン化合物による肝 cyt. P-450 不活性化 機構と同じ活性 oxirene 中間体を経由するもの (B) ${ }^{25)}$ である. 14 を用いる ARM 阻害実験では, 肝 cyt. P-450 の不活性化で生成する緑のへム色 素 ${ }^{26)}$ が生成しない。このことは，(A) の経路を支 
Table I. 19-Substituted steroids as suicide substrates of aromatase

\begin{tabular}{|c|c|c|c|}
\hline Compd. & $\mathrm{R}$ & $\left.\mathrm{Ki}, \mathrm{nM}^{\mathrm{a}}\right)$ & Kinact., $\left.\min ^{-1 b}\right)$ \\
\hline 14 & $\mathrm{CH}_{2} \mathrm{C} \equiv \mathrm{CH}$ & 23 & 0.175 \\
\hline 15 & $(\mathrm{~S})-\mathrm{CH}(\mathrm{OH}) \mathrm{C} \equiv \mathrm{CH}$ & 1000 & 0.066 \\
\hline 17 & $\mathrm{CH}_{2} \mathrm{C} \equiv \mathrm{C}-\mathrm{CH}_{3}$ & 14.6 & - \\
\hline 18 & $\mathrm{CH}=\mathrm{C}=\mathrm{CH}_{2}$ & 13.6 & 0.027 \\
\hline 19 & $\mathrm{CH}_{2}-\mathrm{C} \equiv \mathrm{N}$ & 22.5 & Competitive \\
\hline 20 & $\mathrm{CH}_{2}-\mathrm{CH}=\mathrm{CH}_{2}$ & 12.5 & Competitive \\
\hline 21 & $\mathrm{CHF}_{2}$ & 1000 & 0.023 \\
\hline 24 & $\mathrm{CH}(\mathrm{OH}) \mathrm{CH}_{2} \mathrm{Si}\left(\mathrm{CH}_{3}\right)_{3}$ & 560 & - \\
\hline 25 & $\mathrm{CH}_{2} \mathrm{SH}$ & 106 & - \\
\hline 26 & $\mathrm{CH}_{2} \mathrm{SCH}_{3}$ & 1 & Competitive \\
\hline 27 & $\mathrm{CH}_{2} \mathrm{~N}_{3}$ & 5 & Competitive \\
\hline 28 & (R) - & 7 & Competitive \\
\hline 29 & (R) $-\mathrm{C}$ & 1 & Competitive \\
\hline 30 & $\mathrm{SH}$ & 3.4 & 0.192 \\
\hline 31 & $\mathrm{NH}_{2}$ & - & - \\
\hline
\end{tabular}

a) $\mathrm{Km}$ for aromatase of human placental microsomes ranges between 10 and $100 \mathrm{nM}$, and this pricipally depends on the incubation conditions, espectially, amounts of protein, and the used placenta.

b) Compound of which $K_{\text {inact. }}$ is shown is a suicide substrate ; - : suicide substrate of which $K_{\text {inact. }}$. is not obtained; competitive : competitive inhibitor.

持するが，ARM の特性が明確でないことから， (B)を否定できない。

14 のメチル化体 17 も 14 と同様の阻害活性を 示した ${ }^{27)}$. 一方, エチニル基と幾何学的に類似し た化合物をみると，まず，19-アレン体 18 は強い 自殺基質である.このものは, 肝 cyt. P-450 の アレン化合物による不活性化 ${ }^{28)}$ と同様に, 反応性 の高いアレンオキシドを中間体として，ARMを アルキル化するのであろう (Fig. 3, (C) $)^{25)}$. つ いで, 19-シアノ体 19 や19-ビニル体 20 は, 強力 な拮抗阻害作用を持つものの, もはや時間依存的 な酵素失活作用はない27).

14 は, ヒト乳ガン腫瘍, 皮下脂肪や卵巣 組 織 中 ${ }^{29)}$, さらには MCF-7 ヒト乳ガン細胞 ${ }^{30)}$, M 5480 A Lydig ガン細胞 ${ }^{31}$, JAr 繊毛膜ガント ロホブラス細胞 ${ }^{22}$ の ARM 活性を阻害した. In vivo 実験では, 14 はラットの DMBA 誘発乳ガ
ンを縮小し、ヌードマウスに移植されたヒト卵巣 ガンの増殖を抑制した ${ }^{33)}$. これらの結果は, 14 の 臨床試験の結果に期待をもたせるものである.

次に，19-ハロゲン化物として 19,19-difluoro 体21が開発された ${ }^{34)} .21$ の不活性化機構は，19$\left[{ }^{2} \mathrm{H}\right]$ や 19- $\left[{ }^{3} \mathrm{H}\right]$ 標識体を用いて検討された ${ }^{35)}$. その結果, ARM 不活性化過程で, 19-プロトン が時間依存的, NADPH 依存的さらには蛋白量 依存的に $\mathrm{H}_{2} \mathrm{O}$ としてインキュベーション溶液中 に放出されたが，このとき， $\mathrm{C}_{19}-\mathrm{H}$ 結合の切断が 不活化反応の律速段階ではなかった。これら結果 は, ARM が 21 の19位炭素を攻撃し $21 \rightarrow 22 \rightarrow 23$ の経路で活性体を生成させることを示唆している (Fig. 4).

また，19-OHAの19-シリル誘導体 24 も時間依 存的に ARM を不活性する ${ }^{36)}$. また, この 19deoxy 体は, 可逆的阻害剂であることから，24は 


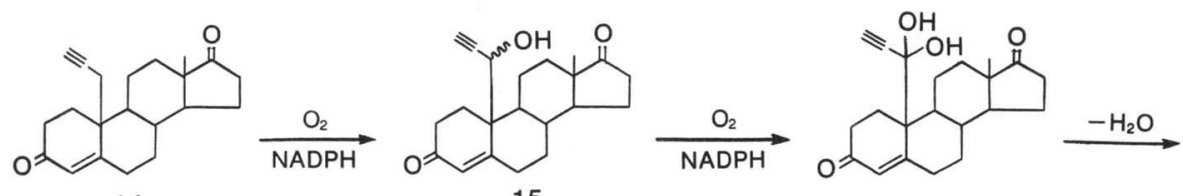

14<smiles>C=C(O)CC12CCC(O)C=C1CCC1C3CCCC3(O)CCC12</smiles>

15

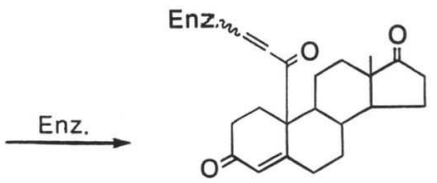

16

(B)

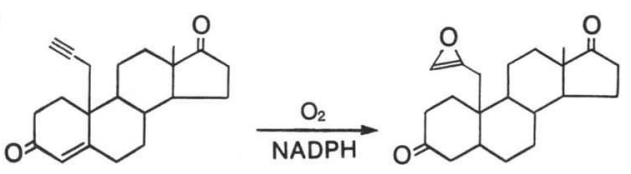

14

(C)

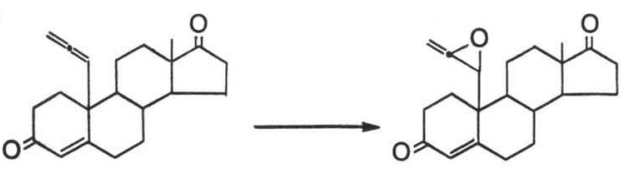

18

Fig. 3. Proposed mechanism for aromatase inactivation by 19-ethynyl and 19-allenyl steroids. ${ }^{25,26)}$

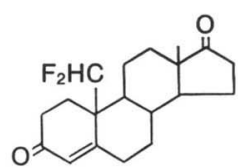

21

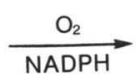

$\underline{22}$

$-\mathrm{HF}$
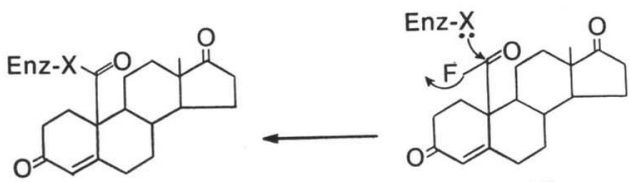

23

Fig. 4. Proposed mechanism for aromatase inactivation by 19,19 -difluoro compound. ${ }^{35,36)}$

コレスラコール側鎖切断酵素の自殺基質と同様の 機構で不活性化するものと推測される (Fig. 5).

幾何学的・電子的に 19-OHA と類似している 19-チオール体 25 は, ARM反応により活性な19スルフェニル体となり不可逆的に酵素を失活させ
るのであろら ${ }^{37)}$. 他方, S-メチル体 26 は, 不可逆 的酵素阻害を示さないが，これは $\mathrm{S}$ 原子が直接一 么の鉄原子に配位するためと考兄られる ${ }^{38)}$.

アジド体 $27^{38)}$, さらには epoxy 体 28 や thiirany 体 2939)なども合成されている。これらは, ARM に強い親和性を有するものの時間依存的に 酵素を失活させない，28 と 29 では，(R)-ジアス テレオマーが（S)-体に比較し Ki 值が $1 / 10$ と $1 / 75$ と, 立体選択性が観察された.

次に，19位炭素原子を $\mathrm{S}$ や原子で置換した化 合物 $30^{40)}$ と $31^{41)}$ が ARM 阻害剤として検討さ れている.この中では，10 $\beta$-チオール体 30 が自 殺基質として確認されたが， 30 は阻害作用も強 く, 19-チオール体 25 と類似の機構がその不可逆 的阻害に関与しているものと思われる.

\section{3-3-2. AならびにB環誘導体}

Fig. 6 に示す 5 つの化合物 32〜36があげられ るが, これらは, 基質 A に二重結合, カルボニル 基やメチル基が導入されたものである．この中 で，32〜34 は古くより ARM の競合阻害剂とし 

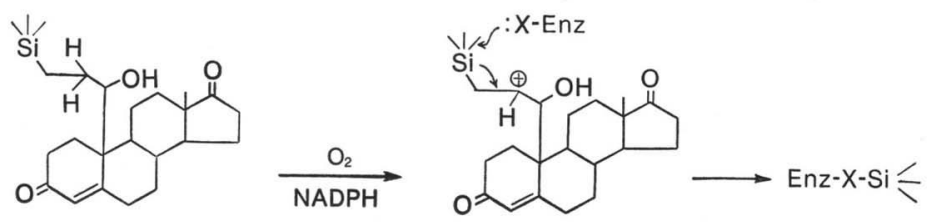

24

Fig. 5. Proposed mechanism for aromatase inactivation by 19 -silyl derivative 24.37)

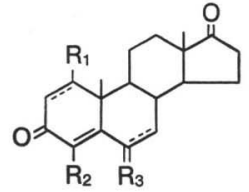

$\begin{array}{ll}32 & \mathrm{R}_{1}=\mathrm{H}, \mathrm{R}_{2}=\mathrm{OH}, \mathrm{R}_{3}=\mathrm{H}_{2} \\ 33 & \mathrm{R}_{1}=\mathrm{R}_{2}=\mathrm{R}_{3}=\mathrm{H}, \triangle^{\prime}, \triangle^{6} \\ \text { 34 } & \mathrm{R}_{1}=\mathrm{R}_{2}=\mathrm{H}, \mathrm{R}_{3}=\mathrm{O} \\ \underset{35}{ } & \mathrm{R}_{1}=\mathrm{CH}_{3}, \mathrm{R}_{2}=\mathrm{H}, \mathrm{R}_{3}=\mathrm{H}_{2}\end{array}$<smiles>[R]C1=CC2=CCC3C4CCC(=O)C4CCC3C2CC1</smiles>

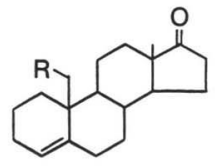

$\stackrel{45}{\sim} \mathrm{R}=\mathrm{H}$

$46 \mathrm{R}=\mathrm{OH}$

$37 \mathrm{R}=\mathrm{OCOCH}_{3}$

38 $\mathrm{R}=\mathrm{OCOH}$

$39 \mathrm{R}=\mathrm{OH}$

$\stackrel{40}{\sim} \mathrm{R}=\mathrm{H}$

Fig. 6. A-, B- or D-ring substituted suicide substrates of aromatase and 3-deoxy steroids as potential inhibitors of it.

て知られていたにもかかわらず，自殺基質として の特性を持つことが判明したのは比較的新しい.

このことは, ARM 反応機構を考学ると当然とも 言光るが，逆に言觉ば，これらの不可逆的不活性 化機構の解明が容易でないことを示唆している. 事実, 今のところ, これらの機構は汇とんど不明 である.しかし，1，4,6-triene 33 と 1,4-diene
36 ${ }^{42)}$ では, Fig. 7 に示す 1 位二重結合からの 1 電子引き抜きの関与する機構が考兄られている.

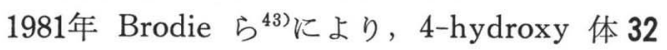
が ARM の自殺基質であることが初めて明らか にされた。 その後の研究で44 46), 32 は乳ガン治療 薬として組織的な臨床試験に供されるまでになっ た. PMSG で誘発されたラットに32を投与する と, 卵巣ミクロゾーム ARM 活性の低下と卵巣 静脈血中エストロゲン濃度の減少がみられる.さ らに, ラットの DMBA 誘発乳ガン腫瘍も32 の投 与により顕著に縮小する。また，この縮小は血中 エストロゲンを生理的濃度に保つことにより妨害 される、これらの事実より，32 投与によるエスト ロゲン生合成阻害と腫瘍縮小との関連が明確とな った. 一方, この縮小能力は, 抗エストロゲンの tamoxifen よりも大きいものであった.

58例（22例がエストロゲンレセプター $(+))$ の 進行した転移性乳ガン患者を対象に，32 の臨床試 験が試みられた ${ }^{47)}$ 。 その結果, 筋肉内投与で14例 (27\%) に部分的または完全な効果が，10例（19 \%) に進行の停止が認められた. 経口投与では, 31 例で 8 例 $(26 \%)$ に部分的効果， 4 例 $(13 \%)$ に進行の停止があった ${ }^{48)}$.

Triene 体 33 は, in vivo 実験で卵巣 ARM 活 性減少と血中エストロゲン濃度低下,さらにはラ ットの DMBA 誘発乳ガンの縮小を引き起こ す ${ }^{49)}$. 1-Methyl 体 35 は, メチル基の導入により $\mathrm{A}$ 環芳香核化が妨害され，かつ $\mathrm{ARM}$ への親和 性が増加された ${ }^{50)} .35$ は, Shering AG グループ

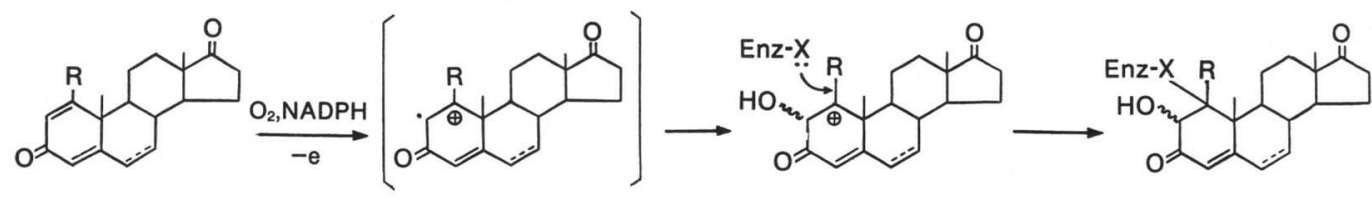

Fig. 7. Proposed mechanism for aromatase inactivation by 1,4 -diene derivative. ${ }^{43}$ 


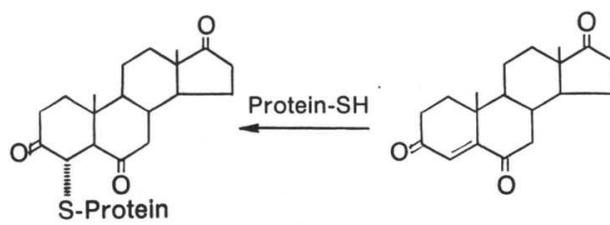

$\stackrel{43}{\sim}$

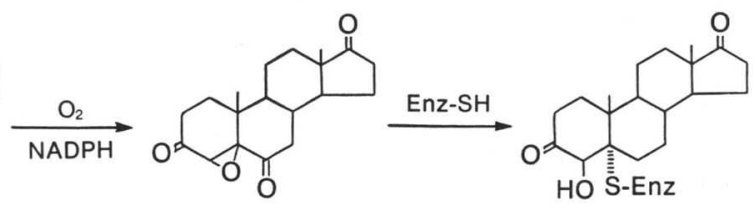

$\stackrel{41}{\sim}$

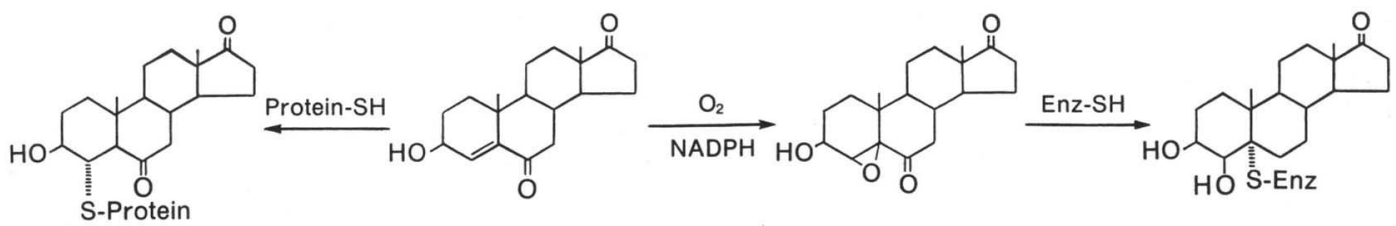

$\stackrel{44}{\sim}$

$\stackrel{39}{\sim}$

$\stackrel{42}{\sim}$

Fig. 8. Proposed sequence for aromatase inactivation by 6 -oxosteroids 34 and 39 .

により前立腺肥大症への適用が検討されてい る ${ }^{46)}$. Testolactone 36 は, D環ラクトンでなく, 1,4-diene 構造が時間依存的不活性化に関与する のであろ 5 ${ }^{42)}$. 36は，ARM 自殺基質としての性 質が明確になる前から乳ガン治療薬として臨床で 使用されている

われわれは, trione 体 34 について $\left[4-{ }^{14} \mathrm{C}\right]$ 標 識体を合成し，自殺基質としての性質を詳細に調 ベた ${ }^{52)}$. その結果, 34 による時間依存的酵素失活 と標識ステロイドのヒト胎盤ミクロゾーム ARM への不可逆的結合が相関すること, ARM の単ク ローン抗体や基質Aがこの不可逆的結合を妨害す ることが明らかとなった，さらには，この不可逆 的蛋白結合体の Raney Ni 処理実験などから，34 の活性代謝物が酵素の活性部位の $\mathrm{S}$ 原子を介して 共有結合し, ARM を失活させたものと考光られ る.

次に, 34 は, 時間依存的 ARM 阻害実験条件 下速やかに $3 \beta$-hydroxy 体 39 に還元された. 注 目すべきことに，この還元反応はステロイド $5 \alpha-$ 還元酵素の特異的阻害剂で完全に抑制された。さ らには, $\left[{ }^{14} \mathrm{C}\right]-39$ を用いる実験などにより，この 還元体は 4-en-3-one 構造を持たない初めての ARM 自殺基質と認定された. 一方, NADPH や $\mathrm{O}_{2}$ の存在しない条件下でも, 34 と 39 は Michael acceptorとしてミクロゾーム蛋白と非酵素的に反 応し, 不可逆的結合体 43 と 44 を与光た ${ }^{53)}$ (Fig. 8).
34 と 39 の $4 \beta, 5 \beta$-epoxides 41 と 42 の化学反 応性や ARM に対する親和性などから, これら epoxides が 34 と 39 の活性分子種でありうるこ とが示唆された (Fig. 8).

次に, $3 \beta$-hydroxy 体の構造活性相関を検討し $た^{54)}$. 3 位に電子求引性基が導入された 3 -acetate 37 と 3-formate 38 が ARM を時間依存的に失活 させ, 特に前者は 3-ケトン体 34 と同程度の強い 阻害活性を示した。また， 3 位に官能基のない 3-deoxy 体 40 は, 基質 Aの位置異性体で, 4-en3-one の代りに 4-en-6-one 構造を持つが, 強力 な拮抗阻害作用を示した。

そこで，3-deoxy 体に着目し，A，B 環にカル ボニル基のない化合物 45 と 46 を合成し, これら の ARM 阻害能力を調べた ${ }^{55)}$. その結果, 両者と も強力な拮抗阻害であったが，特に 19-hydroxy 体 46 は優れたものであった $(\mathrm{Ki}=12.5 \mathrm{nM}) .45$ と46の ARM への親和性は, 基質 $\mathrm{A}$ との 19hydroxy 体 (19-OHA) のとれとの関係とは逆 であり，3-oxo 体と 3-deoxy 体とでは，ARM への結合の仕方に相違のあることが示唆された。 また，これら 3-deoxy 体は, エストロゲンへは 変換しないことから，A や 19-OHA を経由しな いで, 直接 ARM 活性を抑制するのであろう.

6 位置換体では，アフィニティラベル化剂の場 合と全く逆の立体選択性がみられた。すなわら， $6 \beta$-異性体 9 と 11 のみが ARM の自殺基質とな った ${ }^{56,57)}$. このことは, ARM 反応機構や活性部 
位の立体配置などを考觉る上で興味 深い。他の $6 \beta$-bromide 13 は, NADPH 存在下でその非存 在下に比較してょり低濃度で, ARM を時間依存 的に失活させた ${ }^{57)}$. このことは, この不活性化に $17 \beta$-bromoacetyl 基ではなく, $6 \beta$-bromo 置換 基が関与することを示唆している.

19-ノル体で $17 \alpha$-ethynyl 基を持つ 19-norethisterone は, ARM に対して親和性は弱いなが らも，その自殺基質であることが報告されてい る ${ }^{58)}$. このステロイドは, 経口避妊薬の有効成分 の一つであり，いわゆるピル常用婦人と乳ガンと の関係に新しい知見を加觉るものと考光られる.

\section{4. おわりに}

現在, ARM はヒト胎盤ミクロゾームより単一 蛋白として単離されている，そのアミノ酸配列も
明らかにされつつあり, ARM 反応機構や活性中 心部位の構造も近い将来解明されるものと思われ る、このとき, ARM 阻害剂は重要な役割を果た すであろう。

一方, 前述のように, エストロゲン依存性乳ガ ンなどの薬としても ARM は有望である. 現在, 化合物36や非ステロイド系化合物の aminoglutethimide (AG) が臨床に用いられている. これら は選択性に劣るとともに, 特に後者では閉経後の 婦人にのみ有効であることと, 副腎でのコルチコ イドの生合成が抑制されることなどの問題が指摘 されている. 最近, AG や抗真菌剤のイミグゾー ル誘導体の中から, ARM を特異的に阻害するも のも見出されている. 薬としての観点からも， ARM 阻害剂研究の今後の進展が期待される.

\section{文献}

1) Osawa, Y., Tochigi, B., Higashiyama, T., Yarborough, C., Nakamura, T. and Yamamoto, T. : Multiple forms of aromatase and response of breast cancer aromatase to antiplacental aromatase II antibodies. Cancer Pes. (Suppl.), 42 : 3299s-3306s (1982).

2) Longcope, C., Pratt, J.H., Schneider, S.H. and Fineberg, E.S. : Aromatization of androgens by muscle and adipose tissue in vivo. J. Clin. Endocr. Metab., 46 : 146-152 (1978).

3) Berkovitz, G.D., Fujimoto, M., Brown, T.R., Brodie, M.H. and Migeon, C.J. : Aromatase activity in cultured human genital skin fibroblasts. J. Clin. Endocr. Metab., 59 : 665-671 (1984).

4) Kitawaki, J., Yoshida, N. and Osawa, Y. : Endocrinology. $124: 1417-1423$ (1989).

5) Thompson, E.A. Jr. and Siiteri, P.K. : Utilization of oxygen and NADPH by human placental microsomes during aromatization of androstenedione. J. Biol. Chem., 249 : 5364-5372 (1974).

6) Fishman, J. : Biochemical mechanism of aromatization. Cancer Res. (Suppl.), $42: 3277 \mathrm{~s}-3280$ s (1982).

7) Cole, P.A. and Robinson, C.H. : A peroxide model reaction for placental aromatase. J. Am. Chem. Soc., $110: 1284-1285$ (1988).

8) Numazawa, M., Nagaoka, M. and Osawa, Y. : Stereospecific synthesis of $16 \alpha-$ hydroxy-17-oxo steroids by controlled alkaline hydrolysis of corresponding 16bromo 17-ketones and ins reaction mechanism. J. Org. Chem., 47:4024-4029 (1982).

9) Stevenson, D.E., Wright, J.N. and Aktar, M. : Synthesis of 19-functionalised derivatives of $16 \alpha$-hydroxy-testosterone : Mechanistic studies on oestriol biosynthesis. J. Chem. Soc., Chem. Commun., $1985:$ 1078-1080.

10) Numazawa, M., Tsuji, M., Yarborough, C. and Osawa. Y. : Preparation of $\left[1,2-{ }^{3} \mathrm{H}, 4-{ }^{14} \mathrm{C}\right]-16 \alpha$-hydroxyandrostenedione and its use for radiometric determination of human placental aromatase activity. Chem. Pharm. Bull., $35: 2448-$ 2452 (1987).

11) Numazawa, M., Osada, R., Tsuji, M. and Osawa, Y. : High-performance liquid chromatographic determination of aromatization of $16 \alpha$-hydroxylated androgens with human placental microaomes. Anal. Biochem., $146: 75-81$ (1985). 
12) Solo, A.J., Caroli, C., Darvey, M.V., Mckay, T., Slaunwhite, W.D. and Hebborn, P. : $7 \alpha$-Alkyltestosterone derivatives : Synthesis and activity as androgens and as aromatase inhibitors. Syeroids, $40: 603-614$ (1982).

13) Brueggemeier, R.W., Floyd, E.E. and Counsell, R.E. : Synthesis and Biochemical Evaluation of Inhibitors of estrogen biosynthesis. J. Med. Chem., 21 : 1007-1011 (1978).

14) Miyairi, S. and Fishman. J. : 3-Methylene-substituted androgens as novel aromatization inhibitors. Evidence of a requirement for C-3 oxygen in 19-hydroxylations. J. Biol. Chem., $261: 6772-6777$ (1986).

15）沼沢光輝，辻 正親，睦見綾子，黑内賢一，長岡正男：6と 7 位置換アンドロゲンと ヒト胎盤アロマターゼ阻害活性. 東北薬科大学研究年報, 33: 57-62 (1986).

16) Brueggemeier, R.W. and Li, P.-K. : Effects of the aromatase inhibitor $7 \alpha-\left(4^{\prime}-\right.$ amino) phenylthio-4-androstene-3,17-dione on 7,12-dimethylbenz-(a)anthraceneivduced mammary carcinoma in rats. Cancer. Res., 48 : 6808-6810 (1988).

17) Bellino, F.L. and Osawa, Y. : Estrogen synthetase. Effect of sulfhydryl reactive reagents on androgen aromatization by human term placental microsomes. $J$. Steroid Biochem., 13 : 339-344 (1980).

18) Bellino, F.L., Gilani, S.S.H., Eng, S.S., Osawa, Y. and Duax, W.L. : Activesite-directed inactivation of aromatase from human placental microsomes by brominated androgen derivatives. Biochemistry, $15: 4730-4736$ (1976).

19) Numazawa, M., Tsuji, M. and Osawa, Y. : Synthesis and evaluation of bromoacetoxy 4 -androsten-3-ones as active-site-directed inhibitors of human placental aromatase. Steroids, $48: 347-359$ (1986).

20) Snider, C.E. and Brueggemeier, W. : Covalent modifications of aromatase by a radiolabeled irreversible inhibitor. J. Steroid. Biochem., 22 : 325-330 (1985).

21) Brueggemeier, R.W., Snider, C.E. and Kimball, J.G. : A Photoaffinity inhibitor od aromatase. Steroids, $40: 679-689$ (1982).

22) Covey, D.F., Hood, W.F., Beusen, D.D. and Carrell, H.L. : Hydroperoxides as inactivators of aromatase : $10 \beta$-Hydroperoxy-4-estrene-3,17-dione, crystal structure and inactivation characteristics. Biochemistry, $23: 5398-5406$ (1984).

23) White, R.E. and Coon, M.J. : Oxygen activation by cytochrome P-450. Ann. Rev. Biochem., $49: 315-356$ (1980).

24) Covey, D.F., Hood, W.F. and Parikh, V.D. : 10 $\beta$-Propynyl-substituted steroids. Mechanism-based enzyme-activated irreversible inhibitors of estrogen biosynthesis. J. Biol. Chem., 256 : 1076-1079 (1981).

25) Metcalf, B.W., Wright, C.L., Burkhart, J.P. and Johnston, J.O. : Substrateinduced inactivation of aromatase by allenic and acetylenic steroids. J. Am. Chem. Soc., $103: 3221-3222$ (1981).

26) Ortiz de Montellano, P.R. and Kunze, K.L. : Self-catalyzed inactivation of hepatic cytochrome P-450 by ethnyl substrates. J. Biol. Chem., $255:$ 5578-5585 (1980).

27) Johnston, J.O., Wright, C.L. and Metcalf, B.W. : Biochemical and endocrine properties of a mechanism-based inhibitor of aromatase. Endocrinology, 115 : $776-785$ (1984).

28) Ortiz de Monellano, P.R. and Kunze, K.L. : Inactivation of hepatic cytochrome P-450 by allenic substrates. Biochem. Biophys. Res. Commun., 94:443-449(1980).

29) Perel, E., Davis, S.P., Covey, D.F. and Killiger, D.W. : Effects of 4-hydroxy4-androstene-3,17-dione and 10-propagylestr-4-ene-3,17-dione on the metabolism of androstenedione in human breast carcinoma and breast adipose tissue. Steroids, 38 : 397-405 (1981).

30) MacIndoe, J.H., Woods, G.R., Etre, L.A. and Covey, D.F. : Comparative studies of aromatase inhibitors in cultured human breast cancer cells. Cancer Res., (Suppl.), $42: 3378$ s-3381s (1982).

31) Zimniski, S.I., Brandt, M.E., Melner, M.H., Covey, D.F. and Puett, D.:Inhibition of Leydig tumor cell steroidogenesis by 10-propargylestr-4-ene-3,17-dione, an irrevershble aromatase inhibitor. Cancer Res., $45: 4883-4889$ (1985).

32) Johnston, J.O., Wright, C.L. and Metcalf, B.W. : Time-dependent inhibition of 
aromatase in trophoblastic tumor cells in tissue culture. J. Steroid Biochem., $20: 1221-1226$ (1984).

33) Zimniski, S.J., Brandt, M.E., Covey, D.F. and Puett, D. : Inhibition of aromatase activity and of endocrind-responsive tumor growth by 10-propargylestt-4-ene-3, 17 -dione and its 17 -propionate derivative. Steroids, $50: 135-146$ (1987).

34) Marcotte, P.A. and Robinson, C.H. : Inhibition and inactivation of estrogen synthetase (aromatase) by fluorinated substrate analogues. Biochemistry, 21 : 2773-2778 (1982).

35) Furth, P.S. and Robinson, C.H. : Tritium release from $\left[19-{ }^{3} \mathrm{H}\right]-19,19$-difluoroandrost-4-ene-3,17-dione during inactivation of aromatase. Biochemistry, 28 : 1254-1259 (1989).

36) Burkhart, J.P., Weintraub, P.M., Wright, C.L. and Johnston, J.O. : Novel silylated steroids as aromatase inhibitors. Steroids, $45: 357-374$ (1985).

37) Bednarski, P.J., Porubek, D.J. and Nelson, S.D. : Thiol containing androgens as suicide substrate of aromatase. J. Med. Chem., 28 : 775-779 (1985).

38) Wright, J.N., Calder, M.R. and Akhtar, M. : Steroidal C-19 sulphur and nitrogen derivatives designed as aromatase inhibitors. J. Chem. Soc., Chem. Commun., $1985: 1733-1735$.

39) Kellis, J.T. Jr., Childers, W.E., Robinson, C.H. and Vickery, L.E. : Inhibition of aromasase cytochrome $\mathrm{P}-450$ by 10 -oxirane and 10-thiirane substituted androgens. J. Biol. Chem., 262 : 4421-4426 (1987).

40) Bednarski, P.J. and Nelson, S.D. : Interaction of thiol-containing androgens with human placental aromatase. J. Med. Chem., 32 : 203-213 (1989).

41) Lovett, J.A., Darby, M.V. and Counsell R.E. : Synthesis and evaluation of 19-aza- and 19-aminoandrostenedione analogues as potential aromatase inhibitors. J. Med. Chem., $27:$ 734-740 (1984).

42) Covey, D.F. and Hood, W.F. : A new hypothesis based on suicide substrate inhibitor studies for the mechanism of action of aromatase. Cancer Res., (Supll.), 42 : 3327s-3333s (1982).

43) Brodie, A.M.H., Garrett, W.H., Hedrickson, J.R., Tsai-Morris, C.H., Marcotte, P.A. and Robinson, C.H. : Inactivation of aromatase in vivo by 4 -hydroxyandrostenedione and 4-acetoxyandrostenedione and sustained effects in vivo. Steroids, 38 : 693-701 (1981).

44) Brodie, A.M.H., Wing, L.Y., Goss, P., Dowsett, M. and Coombes, R.C. : Aromatase inhibitors and their potential clinical significance. J. Steroid. Biochem., $25: 859-965$ (1986).

45) Brodie, A.M.H., Coombes, R.C. and Dowsett, M. : Aromatase inhibitors : Basic and clinical studies. J. Steroid. Biochem., 27 : 899-903 (1987).

46) Henderson, D. : Aromatase inhibitors : Their biochemistry and clinical potential. J. Steroid. Biochem., 27 : 905-914 (1987).

47) Goss, D.E., Powles, T.J., Dowsett, M., Hutchinson, G., Brodie, A.M.H., Gazet, J.-C. and Coombes, C. : Treatment of advanced postmenopausal breast cancer with an aromatase inhibitor, 4-hydroxy-androstenedione : Phase II report. Cancer Res., 46 : 4823-4826 (1986).

48) Cunnigham, D., Powles, T.J., Dowsett, M., Hutchinson, G., Ford, H.T., Brodie, A.M.H., Gazet, J.-C. and Coombes, R.C. : Oral 4-hydroxy-androstenedione is a new, active endocrine treatment for breast cancer. Cancer Chemother. Pharmac., $20: 253-255$ (1987).

49) Brodie, A.M.H., Brodie, H.J., Garrett, W.M., Hendrickson, J.R., Marsh, D.A. and Tsai-Morris, C.H. : The effect of aromatase inhibitor 1,4,6-androstatriene (ATD) on DMBA-induced mammary tumor in the rat and ins mechanism of action in vivo. Biochem. Pharmacol., $31: 2017-2022$ (1982).

50) Henderson, D., Norbisrath, G. and Kerb, U. : 1-Methyl-1,4-androstadiena-3, 17-dione ( $\mathrm{SH}$ 489): Characterization of an irreversible inhibitor of estrogen biosynthesis. J. Steroid Biochem., 24 : 303-308 (1986).

51) Segaloff, A., Weeth, J.B., Meyer, K.K., Rongone, E.L. and Cunningham, M.E.G. :Hormonal theraphy in cancer of the breast-XIX. Effect of oral administration 
of 1-testololactone on clinical course and hormonal excretions. Cancer, 15 : 633-635 (1962).

52) Numazawa, M., Tsuji, M. and Mutsumi, A. : Studies on aromatase inhibition with 4-androstene-3,6,17-trione : Its 3-reduction and time-dependent irreversible binding to aromatase in human placental microsomes. J. Steroid Biochem., 28 : 337-344 (1987).

53) Numazawa, M., Tsuji, M. and Osada, R. : Studies directed towards a mechanistic evaluation of aromatase inhibition with androst-4-ene-3,6,17-trione : Its reactions with thiols. J. Chem. Res. (M), 1986:718-734.

54) Numazawa, M., Mutsumi, A. and Tsuji, M. : $3 \beta$-Hydroxyandrost-4-en-6-one derinatives as aromatase inhibitors. Steroids in press

55) Numazawa, M., Mutsumi, A., Hoshi, K. and Koike, R. : 19-Hydroxy-4-androsten17-one : Potential competitive inhibitor of estrogen biosynthesis. Biochem. Biophys. Res. Commun., $163: 1003$ (1989).

56) Osawa, Y., Osawa, Y. and Coon, M.J. : Stereochemistry of the functional group determines the mechanism of aromatase inbibition by 6 -bromoandrostenedione. Endocrinology, 121 : 1010-1016 (1987).

57) Numazawa, M., Tsuji, M., Mutsuni, A. and Nagaoka, M. : Time-dependent inactivation of human placental aromatase by bromoacetoxy-4-androsten-3-ones in the presence of NADPH. Chem. Pharm. Bull., $37: 735-737$ (1989).

58) Osawa, Y., Yarborough, C. and Osawa, Y. : Norethisterone, a major ingredient of contraceptive pills, is a suicide inhibitor of estrogen biosynthesis. Science, 215 : 1249-1251 (1982). 